\title{
Contraception-still miles to go: a study among married women in a rural area of West Bengal
}

\author{
Jayita Pal, Shamshad Ahmad*, Arohita Siva
}

Department of Community Medicine, ESI-PGIMSR, ESIC Medical College, Joka, Kolkata, West Bengal, India

Received: 13 June 2017

Accepted: 08 July 2017

\section{*Correspondence:}

Dr. Shamshad Ahmad,

E-mail: ahmad.esi.joka@gmail.com

Copyright: (C) the author(s), publisher and licensee Medip Academy. This is an open-access article distributed under the terms of the Creative Commons Attribution Non-Commercial License, which permits unrestricted non-commercial use, distribution, and reproduction in any medium, provided the original work is properly cited.

\begin{abstract}
Background: Unregulated growth of population is the most important problem that is hindering the socio-economic growth of a developing country like India since its independence. Multiple socio-economic factors are responsible for non-acceptance of contraception. To meet the unmet need these factors are needed to be explored. The current study aimed to assess the rate of acceptance of different contraceptive methods, various socio-demographic factors affecting acceptance and to find out the reasons for non-acceptance among married women of reproductive age group in a rural area of West Bengal.

Methods: An institution based cross sectional study was conducted among 224 married women of reproductive age group with the help of a predesigned, pretested schedule.

Results: Almost entire study population (98.2\%) had the knowledge of any modern accepted method of contraception; health personnel $(91.1 \%)$ being the most common source of knowledge. In majority of cases $(69.6 \%)$ the decision of contraceptive use was taken by the husband and wife jointly. The overall prevalence of current use of contraception was $33.9 \%$ of which most common method adopted was found to be tubectomy (42.1\%). The total unmet need was 50\%. Multivariate analyses revealed that women aged more than 27 years, belonging to Hindu religion, nuclear family of higher per capita income with education of self and husband being up to or above middle level, having at least two leaving issue and one male child had higher odds of ever use of contraception.

Conclusions: To bridge the gap of knowledge and practice intense awareness generating programmes focusing on the local barriers of contractive practice were the need of the hour to address this alarming public health problem.
\end{abstract}

Keywords: Contraception, Married women, Rural, West Bengal

\section{INTRODUCTION}

Uncontrolled growth of population is the single most important problem that India is facing at present. The country officially obtained the title of the world's second population 'billionaire' on the $11^{\text {th }}$ of May, 2000 and it adds about 10 lakh persons to its population every fortnight and about one Australia every eight month. ${ }^{1,2}$ By 2045 or earlier, India would overtake China as the world's most populous Nation. ${ }^{3}$ Population control still remains a distant dream in India despite of availability of a wide range of contraceptives and mass media campaigns and awareness programs. A robust Family Planning Program had been launched by the Government earlier in 1952 and India was the first country in the world to do so, though it had not yet achieved the expected outcome. ${ }^{4}$

Multiple socio-economic, cultural factors, taboos, misconceptions are playing against the use of contraceptives among the sexually active women which are ultimately hindering the socio-economic growth of 
this country. 1,5 According to National Family Health Survey-3 (NFHS-3) the unmet need for family planning is 13 per cent in India and 8 percent in West Bengal, whereas District Level Household and Facility Survey-3 (DLHS-3) has found the unmet need of contraception to be as high as 21.3 per cent in India, with 7.9 per cent and 13.4 per cent for spacing and limiting respectively. 6,7

Too early, too many and too frequent pregnancies were the most important risk factors for maternal and child mortality. Lack of access to safe and legal termination-ofpregnancy services, lack of awareness about abortion rights, and stigma concerning the procedure contribute to women's reliance on unsafe means to terminate unwanted pregnancy. ${ }^{8}$ Hence knowledge about ideal contraception and its acceptance is of utmost importance for birth control, proper spacing and thereby reducing the maternal mortality. Women need the ability to decide when to start and finish childbearing, how long to wait after the birth of one child before becoming pregnant with the next and how many children to have. ${ }^{9}$ Every woman should have the easy access to medical and social services. ${ }^{10}$ In a developing country like India where still male-child preference is playing a major role in shaping contraceptive practices, mothers adopt these methods only after completion of family with birth a of male child. Rejection of long term spacing methods are mainly due to fear of side-effects, lack of proper knowledge, followed by husbands' objection, desire for more children and health reasons. ${ }^{11}$

The National Family Welfare Programme has achieved only a modest reduction in the population growth. Though all contraceptive methods are promoted through Cafeteria Approach, female sterilization continues to be the most preferred method. ${ }^{12}$ Despite widespread availability and ubiquitous knowledge, other contraceptive methods are often not used regularly or effectively. However, as the relative effect of each factor differs from one population to another, it is of interest to study their association and contribution in any defined population. Although there is ample information in this aspect, area specific focused information is necessary for delivery of need based health services.

With this background, an attempt was made with this research to assess the rate of acceptance of various contraceptive methods, various socio-demographic factors affecting acceptance and to find out the reasons for non-acceptance among married women of reproductive age group in a rural area of West Bengal.

\section{METHODS}

An institution based cross-sectional study had been conducted in Nasibpur Union Health Centre (NUHC) of Singur block, Hooghly district, West Bengal from $15^{\text {th }}$ August-14 ${ }^{\text {th }}$ November 2012. All the married women of reproductive age group (15-49 years) attending general OPD of NUHC during the study period were the study population. Institutional ethical clearance was obtained and informed consent was taken from every participant. Pregnant women, lactating mothers (upto 6 months postpartum), women who were separated or widowed, who had undergone hysterectomy or achieved menopause and who did not give consent were excluded from the study. Thus, a total of 224 participants were included in the study.

The study tool consisted of a questionnaire which was first prepared in English. Then it was translated into Bengali by a linguistic expert keeping semantic equivalence. To check the translation, it was retranslated back into English by two independent researchers who were unaware of the first English version. Face validity of each item had been checked from previous researches in presence of experts. They also decided the content validity of each domain. Reliability had been checked (Cronbach's alpha=0.9). Pretesting followed by pilot testing was done. Necessary corrections and modifications were made accordingly. Exit interview was conducted for every participant with this schedule.

Data thus collected had been entered and analyzed in SPSS 20.0 software. Odds ratios (univariate regression) were calculated to predict the strength of association between the dependent and the independent variables. Multivariate logistic regression had been done to find out the strength of association between dependent variable and the independent variables after adjusting for all the independent variables. All the independent variables which were significantly associated with dependent variable in univariate regression or having biological plausibility to be associated with dependent variable, were entered in the multivariate logistic model (LINK FUNCTION=LOGISTIC) using enter method. Hosmer Lemeshow test was done to check model fitness ( $>>0.05=$ good fit). Nagelkerke R square (a pseudo R2) value had been mentioned in each model to demonstrate the proportion of variability of the dependent variable explained by the predictor variables.

\section{RESULTS}

Majority of study population belonged to the age group of $15-24$ years $(42.9 \%)$ with the mean age of $28 \pm 8.076$ years, Hindu religion $(75.9 \%)$, educated up to middle level $(33 \%)$, joint family $(58 \%)$, lower middle socioeconomic class according to Modified B. G. Prasad scale $2012(56.25 \%)$ and with majority of their husband educated up to middle level (25\%).

Most of the women got married between the age group of $18-20$ years $(58 \%)$ with mean age at first marriage of $18.7 \pm 1.835$ years and majority delivered their 1 st child between 19-21 years (42\%) with mean age at first child birth of $20.75 \pm 2.39$ years. More than half of the participants were not having not having any male child $(61.6 \%)$ and $32.1 \%$ of them did not have any issue yet. 
Table 1: Knowledge regarding different contraceptive methods, $\mathbf{n}=\mathbf{2 2 4}$.

\begin{tabular}{|lll|}
\hline $\begin{array}{l}\text { Different methods of } \\
\text { contraception }\end{array}$ & $\begin{array}{l}\text { Knowledge } \\
\text { (yes) } \\
\text { Frequency }\end{array}$ & $\%$ \\
\hline $\begin{array}{l}\text { Any method } \\
\text { (Approved } \\
\text { modern/traditional) }\end{array}$ & 220 & 98.2 \\
\hline Any modern method & 220 & 98.2 \\
\hline Female sterilization & 218 & 97.3 \\
\hline Male sterilization & 136 & 60.7 \\
\hline OCP & 220 & 98.2 \\
\hline IUCD & 144 & 64.3 \\
\hline $\begin{array}{l}\text { Injectable contraceptives } \\
\text { Male condom }\end{array}$ & 28 & 12.5 \\
\hline Female condom & 214 & 95.5 \\
\hline $\begin{array}{l}\text { Any other modern method } \\
\text { (Like vaginal sponge etc.) }\end{array}$ & 8 & 8.0 \\
\hline Emergency contraception & 52 & 3.6 \\
\hline OCP + IUCD+ condom & 144 & 23.2 \\
\hline Any traditional method & 178 & 64.3 \\
\hline Withdrawal method & 136 & 79.5 \\
\hline Calendar method & 140 & 60.7 \\
\hline Lactational amenorrhea & 112 & 62.5 \\
\hline & & 50.0 \\
\hline
\end{tabular}

Almost everyone (98.2\%) of the Participants were aware of any modern method of contraception, $64.3 \%$ of them knew about all the three approved modern methods (OCP+ IUCD+ condom) and only $23.2 \%$ of them were aware about emergency contraception (Table 1).

Table 2: Practice of contraception, $n=224$.

\begin{tabular}{|c|c|c|}
\hline \multicolumn{3}{|l|}{ Practice of contraception } \\
\hline \multirow{2}{*}{ Methods of contraception } & \multicolumn{2}{|l|}{ Practice (yes) } \\
\hline & Frequency & $\%$ \\
\hline $\begin{array}{l}\text { Contraception: ever-used } \\
(\mathrm{n}=224)\end{array}$ & 120 & 53.6 \\
\hline \multicolumn{3}{|c|}{ Contraception: currently using $(n=224)$} \\
\hline Modern accepted method only & 76 & 33.9 \\
\hline $\begin{array}{l}\text { Traditional method } \\
\text { (calendar/withdrawal) }\end{array}$ & 60 & 26.8 \\
\hline $\begin{array}{l}\text { Not using any method } \\
\text { (modern/traditional) }\end{array}$ & 88 & 39.2 \\
\hline \multicolumn{3}{|c|}{ Type of contraception: currently using $(n=38)$} \\
\hline Tubectomy & 32 & 42.1 \\
\hline OCP & 18 & 23.7 \\
\hline IUCD & 12 & 15.8 \\
\hline Condom & 14 & 18.4 \\
\hline \multicolumn{3}{|l|}{ Met/unmet need of contraception } \\
\hline Met need & 76 & 33.9 \\
\hline Unmet need for spacing & 90 & 40.2 \\
\hline Unmet need for limiting & 22 & 9.8 \\
\hline Wants to be pregnant & 36 & 16.1 \\
\hline
\end{tabular}

Regarding the source of knowledge health personnel $(91.1 \%)$ was the most common source of information followed by mass media $(75.9 \%)$, relatives $(67.9 \%)$, neighbors $(52.7 \%)$ and friends $(44.6 \%)$.

In most of the cases decision regarding practice of contraception had been taken by the husband and wife jointly (69.6\%), whereas in $24.1 \%$ and $6.3 \%$ cases husband and mother-in -law was the main decision maker respectively.

More than half of the study subjects had used any approved method of contraception at least once in their lifetime since marriage, though current users were only $33.9 \%$. Female sterilization $(23.7 \%)$ was found to be most common method among current users. Total unmet need of contraception (spacing + limiting) was $50 \%$ (Table 2).

Multivariate analyses revealed that women aged more than 27 years, belonging to Hindu religion, nuclear family of higher per capita income with education of self and husband being up to or above middle level, having at least two leaving issue and at least one male child had higher odds of ever use of contraception.

Another model revealed that women aged more than 27 years, belonging to nuclear family, higher per capita income with education of self and husband being up to or above middle level, having at least two leaving issue and at least one male child had higher odds of current use of contraception (Table 3).

Desire of children $(39.4 \%)$, fear of side effects $(32.7 \%)$, interference with body's normal process $(39.4 \%)$, health concerns $(37.5 \%)$, wish of a male child (26.9\%), opposition from family $(24.04 \%)$ were the most commonly found causes of non-acceptance or discontinuation of contraception among the study population (Table 4).

\section{DISCUSSION}

The present study assessed the knowledge and practice regarding contraception among married women. According to NFHS-3, 97.6\%, 96.2\%, 77.1\%, 82.2\%, $63.5 \%, 68.4 \%$ and $8.1 \%$ of eligible couples had knowledge regarding any modern method, female sterilization, male sterilization, OCP, IUCD, male condom, emergency contraceptives respectively in rural India. ${ }^{6}$ The current study as well as a study in rural Haryana also found the similar results. ${ }^{13}$

Saluja $\mathrm{N}$ et al revealed that the most common source of knowledge for all couples in general was the Exposure to family planning messages $(72.0 \%)$ followed by discussion with doctors and other health care workers (42.6\%), whereas the current study showed the most common source of knowledge regarding contraceptives was health personnel $(91.1 \%){ }^{13}$ 
Table 3: Determinants of ever use and current use of contraception: Bi-variate and Multivariate analyses ( $\mathrm{n}=\mathbf{2 2 4}$ ).

\begin{tabular}{|c|c|c|c|c|c|c|c|c|c|c|}
\hline \multirow[t]{2}{*}{ Variables } & \multicolumn{2}{|c|}{$\begin{array}{l}\text { Contraception } \\
\text { (ever use) }\end{array}$} & \multirow{2}{*}{$\begin{array}{l}p \\
\text { value }\end{array}$} & \multirow{2}{*}{$\begin{array}{l}\text { OR } \\
\text { (CI) }\end{array}$} & \multirow{2}{*}{$\begin{array}{l}\text { AOR } \\
(\mathrm{CI})\end{array}$} & \multicolumn{2}{|c|}{$\begin{array}{l}\text { Contraception } \\
\text { (current use) }\end{array}$} & \multirow{2}{*}{$\begin{array}{l}\mathrm{p} \\
\text { value }\end{array}$} & \multirow{2}{*}{$\begin{array}{l}\text { OR } \\
\text { (CI) }\end{array}$} & \multirow{2}{*}{$\begin{array}{l}\text { AOR } \\
(\mathrm{CI})\end{array}$} \\
\hline & $\begin{array}{l}\text { Yes } \\
\text { No (\%) }\end{array}$ & $\begin{array}{l}\text { No } \\
\text { No }(\%)\end{array}$ & & & & $\begin{array}{l}\text { Yes } \\
\text { No }(\%)\end{array}$ & $\begin{array}{l}\text { No } \\
\text { No }(\%)\end{array}$ & & & \\
\hline \multicolumn{11}{|l|}{ Age group } \\
\hline$<27$ years & $18(16.7)$ & $90(83.3)$ & \multirow[b]{2}{*}{0.000} & 1 & 1 & $6(5.6)$ & $102(94.4)$ & \multirow[b]{2}{*}{0.000} & 1 & 1 \\
\hline$\geq 27$ years & $88(87.9)$ & $28(12.1)$ & & $\begin{array}{l}15.7 \\
(12.54- \\
85.77)\end{array}$ & $\begin{array}{l}8.66 \\
(5.80- \\
64.54)\end{array}$ & $\begin{array}{l}70 \\
(60.3)\end{array}$ & $\begin{array}{l}46 \\
(39.7)\end{array}$ & & $\begin{array}{l}25.86 \\
(12.67- \\
76.8)\end{array}$ & $\begin{array}{l}10.9 \\
(6.56- \\
56.4)\end{array}$ \\
\hline Hindu & $\begin{array}{l}106 \\
(62.4)\end{array}$ & $\begin{array}{l}64 \\
(37.6)\end{array}$ & \multirow[t]{2}{*}{0.001} & $\begin{array}{l}4.73 \\
(1.80- \\
12.43)\end{array}$ & $\begin{array}{l}2.22 \\
(1.13- \\
8.60)\end{array}$ & $\begin{array}{l}64 \\
(37.6)\end{array}$ & $\begin{array}{l}106 \\
(62.4)\end{array}$ & \multirow[t]{2}{*}{0.011} & $\begin{array}{l}2.11 \\
(1.23- \\
17.56)\end{array}$ & $\begin{array}{l}1.02 \\
(0.67- \\
5.24)\end{array}$ \\
\hline Muslim & $14(25.9)$ & $40(74.1)$ & & 1 & 1 & $12(22.2)$ & $42(77.8)$ & & 1 & 1 \\
\hline \multicolumn{11}{|l|}{ Family type } \\
\hline Nuclear & $\begin{array}{l}72 \\
(97.9)\end{array}$ & $\begin{array}{l}22 \\
(2.1)\end{array}$ & \multirow[t]{2}{*}{0.000} & $\begin{array}{l}5.59 \\
(3.01- \\
38.04)\end{array}$ & $\begin{array}{l}4.89 \\
(2.80- \\
31.23)\end{array}$ & $62(66)$ & $32(34)$ & \multirow[t]{2}{*}{0.000} & $\begin{array}{l}16.05 \\
(7.89- \\
67.78)\end{array}$ & $\begin{array}{l}7.79 \\
(5.45- \\
56.57)\end{array}$ \\
\hline Joint & $48(21.5)$ & $82(78.5)$ & & 1 & 1 & $14(10.8)$ & $116(89.2)$ & & 1 & 1 \\
\hline \multicolumn{11}{|c|}{ Education of women } \\
\hline Up to primary & $12(13.6)$ & $\begin{array}{l}76 \\
(86.4)\end{array}$ & \multirow[b]{2}{*}{0.000} & 1 & 1 & $\begin{array}{l}6 \\
(6.8)\end{array}$ & $\begin{array}{l}82 \\
(93.2)\end{array}$ & \multirow[b]{2}{*}{0.000} & 1 & 1 \\
\hline Middle and above & $\begin{array}{l}108 \\
(79.4)\end{array}$ & $\begin{array}{l}28 \\
(20.6)\end{array}$ & & $\begin{array}{l}24.42 \\
(10.61- \\
69.28)\end{array}$ & $\begin{array}{l}8.02 \\
(5.34- \\
84.52)\end{array}$ & $\begin{array}{l}70 \\
(51.5)\end{array}$ & $\begin{array}{l}66 \\
(48.5)\end{array}$ & & $\begin{array}{l}14.49 \\
(6.76- \\
34.33)\end{array}$ & $\begin{array}{l}6.76 \\
(4.14- \\
23.4)\end{array}$ \\
\hline \multicolumn{11}{|l|}{ Education of husband } \\
\hline Up to primary & $10(11.6)$ & $76(88.4)$ & \multirow[b]{2}{*}{0.000} & 1 & 1 & $12(14)$ & $74(86)$ & \multirow[b]{2}{*}{0.000} & 1 & 1 \\
\hline Middle and above & $\begin{array}{l}110 \\
(79.7)\end{array}$ & $\begin{array}{l}28 \\
(20.3)\end{array}$ & & $\begin{array}{l}29.86 \\
(9.92- \\
89.84)\end{array}$ & $\begin{array}{l}16.7 \\
(10.89- \\
58.6)\end{array}$ & $\begin{array}{l}64 \\
(46.4)\end{array}$ & $\begin{array}{l}74 \\
(53.6)\end{array}$ & & $\begin{array}{l}5.33 \\
(2.34- \\
15.67)\end{array}$ & $\begin{array}{l}2.12 \\
(1.44- \\
20.02)\end{array}$ \\
\hline \multicolumn{11}{|l|}{ Age at marriage } \\
\hline$<19$ years & $40(37.7)$ & $\begin{array}{l}66 \\
(62.3)\end{array}$ & & 1 & 1 & $\begin{array}{l}30 \\
(28.3)\end{array}$ & $\begin{array}{l}76 \\
(71.7)\end{array}$ & \multirow{2}{*}{0.019} & $\begin{array}{l}1.62 \\
(1.03- \\
6.78)\end{array}$ & $\begin{array}{l}0.98 \\
(0.23- \\
4.152)\end{array}$ \\
\hline$\geq 19$ years & $\begin{array}{l}80 \\
(67.8)\end{array}$ & $\begin{array}{l}38 \\
(32.2)\end{array}$ & 0.001 & $\begin{array}{l}3.474 \\
(1.59- \\
7.56)\end{array}$ & $\begin{array}{l}1.12 \\
(0.79- \\
6.56)\end{array}$ & $\begin{array}{l}46 \\
(39.0)\end{array}$ & $\begin{array}{l}72 \\
(61.0)\end{array}$ & & 1 & \\
\hline \multicolumn{11}{|l|}{ Age at $1^{\text {st }}$ child birth } \\
\hline$<21$ years & $44(40.0)$ & $66(60.0)$ & \multirow[b]{2}{*}{0.006} & 1 & 1 & $32(29.1)$ & $78(70.9)$ & & 1 & 1 \\
\hline$>=21$ years & $76(66.7)$ & $\begin{array}{l}38 \\
(33.3)\end{array}$ & & $\begin{array}{l}3.0 \\
(1.58- \\
18.86)\end{array}$ & $\begin{array}{l}1.54 \\
(0.88- \\
3.57)\end{array}$ & $\begin{array}{l}44 \\
(38.6)\end{array}$ & $\begin{array}{l}70 \\
(61.4)\end{array}$ & 0.025 & $\begin{array}{l}1.53 \\
(0.67- \\
4.16)\end{array}$ & $\begin{array}{l}0.87 \\
(0.23- \\
3.39)\end{array}$ \\
\hline No of living children & & & & & & & & & & \\
\hline$<2$ & $36(27.7)$ & $94(72.3)$ & & 1 & 1 & $16(12.3)$ & $114(87.7)$ & & 1 & 1 \\
\hline$\geq 2$ & $84(89.4)$ & $\begin{array}{l}10 \\
(10.6)\end{array}$ & 0.000 & $\begin{array}{l}21.93 \\
(12.33- \\
63.42)\end{array}$ & $\begin{array}{l}10.36 \\
(7.92- \\
54.2)\end{array}$ & $\begin{array}{l}60 \\
(63.8)\end{array}$ & $\begin{array}{l}34 \\
(36.2)\end{array}$ & 0.000 & $\begin{array}{l}12.57 \\
(7.06- \\
23.56)\end{array}$ & $\begin{array}{l}8.13 \\
(6.19- \\
20.03)\end{array}$ \\
\hline No. of male children & & & & & & & & & & \\
\hline 0 & $42(30.4)$ & $96(69.6)$ & & 1 & 1 & $18(13.4)$ & $120(86.6)$ & & 1 & 1 \\
\hline $1-2$ & $74(90.2)$ & $8(9.8)$ & 0.000 & $\begin{array}{l}21.14 \\
(6.68- \\
66.9)\end{array}$ & $\begin{array}{l}9.34 \\
(7.87- \\
56.04)\end{array}$ & $\begin{array}{l}58 \\
(70.7)\end{array}$ & $\begin{array}{l}24 \\
(29.3)\end{array}$ & 0.000 & $\begin{array}{l}16.11 \\
(8.89- \\
34.34)\end{array}$ & $\begin{array}{l}9.14 \\
(5.46- \\
21.34)\end{array}$ \\
\hline Social class & & & & & & & & & & \\
\hline Up to Middle & $\begin{array}{l}80 \\
(81.6)\end{array}$ & $\begin{array}{l}18 \\
(18.4)\end{array}$ & 0.000 & $\begin{array}{l}9.56 \\
(4.77- \\
34.03)\end{array}$ & $\begin{array}{l}2.67 \\
(1.38- \\
36.89)\end{array}$ & $\begin{array}{l}60 \\
(61.2)\end{array}$ & $\begin{array}{l}38 \\
(38.8)\end{array}$ & 0.000 & $\begin{array}{l}10.85 \\
(6.42- \\
25.78)\end{array}$ & $\begin{array}{l}5.13 \\
(2.34- \\
16.67)\end{array}$ \\
\hline $\begin{array}{l}\text { Lower middle and } \\
\text { lower }\end{array}$ & $40(31.75)$ & $86(68.25)$ & & 1 & 1 & $16(12.7)$ & $110(87.3)$ & & 1 & 1 \\
\hline $\begin{array}{l}\text { Hosmer Lemeshow } \\
\text { test }\end{array}$ & 0.67 & & & & & 0.34 & & & & \\
\hline Nagelkerke $\mathrm{R}^{2}$ & 0.721 & & & & & 0.615 & & & & \\
\hline
\end{tabular}


Table 4: Cause of non-acceptance/discontinuation of contraceptives $(n=104)$

\begin{tabular}{|lll|}
\hline $\begin{array}{l}\text { Cause of non } \\
\text { acceptance/Discontinuation* }\end{array}$ & Frequency & $\%$ \\
\hline Desire of children & 41 & 39.4 \\
\hline Fear of side effects & 34 & 32.7 \\
\hline Opposition from family & 25 & 24.04 \\
\hline Not having sex/infrequent sex & 14 & 13.46 \\
\hline Want a male child & 28 & 26.9 \\
\hline Recently married & 18 & 17.3 \\
\hline No knowledge about source & 5 & 4.8 \\
\hline Anti-religion & 15 & 14.4 \\
\hline Inconvenient for use & 20 & 19.2 \\
\hline $\begin{array}{l}\text { Interferes with body's normal } \\
\text { process }\end{array}$ & 41 & 39.4 \\
\hline Costs too much & 9 & 8.65 \\
\hline Lack of access/source too far & 19 & 18.26 \\
\hline Health concerns & 39 & 37.5 \\
\hline
\end{tabular}

A study by Manna $\mathrm{N}$ et al in rural West Bengal found in $85.2 \%$ of cases husbands were the main decision maker regarding contraceptive use, while inconsistent with this finding the current study showed in majority of the cases $(69.6 \%)$ decision were taken by husband and wife jointly. ${ }^{14}$

As per NFHS 3 couple protection rate (CPR) of rural India was $45.3 \% .^{6} \mathrm{~A}$ study in rural Haryana and rural West Bengal revealed the CPR to be $59.2 \%$ and $33.3 \%$ respectively. ${ }^{13,14}$ The prevalence of contraceptive use among the married women attending the study setting of the current study was found to be $33.9 \%$. The unmet need of family planning was found to be $50 \%$ in this study which corroborated well with other researches by Manna $\mathrm{N}$ et al $(66.67 \%)$ and by Saluja $\mathrm{N}$ et al $(41.61 \%)$, whereas the finding was not consistent with the results of a study by Chakraborty $\mathrm{N}$ et al which revealed the unmet need to be $26.4 \%$ only. ${ }^{13-15}$ According to NFHS $3^{6}$ prevalence of practice of different contraceptive methods were $37.1 \%$, $2.8 \%, 1.1 \%$ and $3.2 \%$ for female sterilization, OCP, IUCD and condom respectively. A study by Manna $\mathrm{N}$ et al showed them to be $41.19 \%, 20.58 \%, 20.58 \%$ and $17.65 \%$ respectively, whereas the present study found more or less consistent results $(42.1 \%, 23.7 \%, 15.8 \%$ and $18.4 \%){ }^{14}$

Regarding the different causes of non-acceptance or discontinuation of contraceptive use a study in Chanai village revealed the common causes to be desire of children $(25.85 \%)$, fear of side effects (16.34\%), opposition from family $(14.06 \%)$ and menopausal (14.06\%); whereas Manna $\mathrm{N}$ et al found the causes were desire to be pregnant $(64.29 \%)$, wish of a male child $(14.29 \%)$, no idea about the source of availability $(3.57 \%)$, no faith in contraceptives $(1.79 \%)$, considered using it as a social taboo (3.57\%) and opposition from husband side $(12.50 \%){ }^{3,14}$ The current study found out that the common causes of non-acceptance among the study population were desire of children $(39.3 \%)$, fear of side effects $(32.1 \%)$, interference with body's normal process $(38.4 \%)$, health concern $(37.5 \%)$, wish of a male child $(26.9 \%)$ and opposition from family $(24.04 \%)$.

Regarding the determinants of contraceptive use Chakraborty $\mathrm{N}$ et al revealed age, educational status of women and their husbands, socioeconomic status, age at marriage and age at first pregnancy were having statistically significant association $(p<0.05)$ with family planning; whereas multivariate analyses in current study found that that age, religion, type of family, socioeconomic status, education of the woman and her husband, number of leaving issue and male child had significant impact on the ever use of contraception ( $p$ $<0.05) .{ }^{15}$

The current study was an institution based study with inclusion of small study population without application of proper sampling technique. Considering this limitation, further community based researches with larger sample size to be performed for better representation of the study area.

\section{CONCLUSION}

The present study revealed that unmet need of contraception was quite high among the study population, though knowledge regarding contraception was satisfactory. There is an urgent need of awareness generating programmes to address this problem by breaking the common barriers of contraceptive practice like gender bias, misconception regarding side effects and related health problems etc. Peripheral health workers should be trained regularly regarding this topic so that they can motivate more and more eligible couples to adopt an accepted method of contraception.

Funding: No funding sources

Conflict of interest: None declared

Ethical approval: The study was approved by the Institutional Ethics Committee

\section{REFERENCES}

1. Chacko E. Women's use of contraception in rural India: A village-level study. Health Place. 2001;7:197-208

2. Kishore J. National health programmes of India. Fifth edition, Century Publication. New Delhi; 2005.

3. Murarkar SK, Soundale SG, Lakade RN. Study of contraceptive practices and reasons for not accepting contraceptives in rural India:Chanai village as a case study. Indian J Sci Technol. 2011;4(8):915-6.

4. National Family Welfare Programme. Available at http://pbhealth.gov.in/pdf/FW.pdf. Last accessed on October 1, 2015.

5. Agarwal A. Social classification: the need to update in the present scenario. Indian $\mathrm{J}$ Comm Med. 2008;33(1):50-1. 
6. IIPS. National family health survey (NFHS-3), 200506. Mumbai: International Institute for Population Studies; 2007. Available at http://www.mohfw.nic.in/nfhs3/index.htm. Accessed on October 1, 2015.

7. District level household and facility survey III 200708 (DLHS III). Ministry of health and family welfare,Government of India. Available at http://www.rchiips.org/pdf/INDIA_REPORT_DLHS -3.pdf. Assessed on October 9,2015.

8. Haldar A, Baur B, Das P, Misra R, Pal R, Roy P R. Contraceptive practices and associated social covariates: an experience from two districts of West Bengal, India. Nepal J Epidemiol. 2012;2(4):219-25.

9. Information Bulletin, 2004. The impact of unmet family planning needs on women's health. ICRW. Available at www.ICRW.org. Last accessed on $20^{\text {th }}$ May, 2017.

10. Takrouri MSM. Reproductive Health: The issues of maternal morbidity and mortality. Internet $\mathbf{J}$ Health 2004;3(2).

11. Nayer I, Akter SF, Hossain S, Luci RH. Acceptance of long-term contraceptive methods and its related factors among the eligible couples in a selected union. Bangladesh Med Res Counc Bull. 2004;30(1):31-5.

12. Phillips JF, Mundigo A, Chamratrithirong A. The correlates of continuity in contraceptive use. J Family Welfare. 1990;36(3):3-17.

13. Saluja N, Sharma S, Choudhary S, Gaur D, Pandey S. Contraceptive knowledge, attitude and practice among eligible couples of rural Haryana. Internet $\mathbf{J}$ Health-Dec 2010;12(1):1.

14. Manna N, Basu G. Contraceptive methods in rural area of West Bengal, India. Sudanese J Public Health. 2011;6(4):164-9.

15. Chakraborty N, Roy SK, Mandal AK. Use of family planning methods and unmet need of contraception among married women in a rural area of West Bengal: a cross-sectional study. IOSR. 2016;15(2):24-9.

Cite this article as: Pal J, Ahmad S, Siva A.

Contraception-still miles to go: a study among married women in a rural area of West Bengal. Int $\mathbf{J}$ Reprod Contracept Obstet Gynecol 2017;6:3618-23. 